\title{
Laura Miguélez-Cavero
}

Triphiodorus, The Sack of Troy 


\title{
TEXTE UND KOMMENTARE
}

Eine altertumswissenschaftliche Reihe

\author{
Herausgegeben von \\ Siegmar Döpp, Adolf Köhnken, Ruth Scodel
}

Band 45

De Gruyter 


\title{
Triphiodorus, The Sack of Troy
}

A General Study and a Commentary

\author{
by \\ Laura Miguélez-Cavero
}

De Gruyter 
ISBN 978-3-11-028520-8

e-ISBN 978-3-11-028530-7

ISSN 0563-3087

\section{Library of Congress Cataloging-in-Publication Data}

A CIP catalog record for this book has been applied for at the Library of Congress

Bibliographic information published by the Deutsche Nationalbibliothek

The Deutsche Nationalbibliothek lists this publication in the Deutsche Nationalbibliografie; detailed bibliographic data are available in the Internet at http://dnb.d-nb.de.

(C) 2013 Walter de Gruyter GmbH, Berlin/Boston

Typesetting: Dörlemann Satz GmbH \& Co. KG, Lemförde

Printing: Hubert \& Co. GmbH \& Co. KG, Göttingen

$\infty$ Printed on acid-free paper

Printed in Germany

www.degruyter.com 
"In a way, I suppose, I think of poems as a sort of animal. They have their own life, like animals, by which I mean that they seem quite separate from any person, even from their author, and nothing can be added to them or taken away without maiming and perhaps even killing them. And they have a certain wisdom. They know something special ... something perhaps which we are very curious to learn" (Ted Hughes, Poetry in the Making, London 1967, 15).

Poems and dreams are birds of the same feather. "Ein Traum ist wie ein Tier, aber ein unbekanntes, und man übersieht nicht seine Glieder. Die Deutung ist ein Käfig, doch der Traum ist nie darin" (Elias Canetti, Die Provinz des Menschen. Aufzeichnungen 1942-1972, München 1973, 163). 
